\title{
Regulation of IGF-I and porcine oviductal secretory protein (pOSP) secretion into the pig oviduct in the peri-ovulatory period, and effects of previous nutrition
}

\author{
Susan NovaK $^{\text {a*}}$, Brian K. Treacy ${ }^{\mathrm{a}}$, Fernanda R.C.L. AlmeIDA ${ }^{\mathrm{a}}$, \\ Jiude MAO ${ }^{\mathrm{a}}$, William C. BuHI ${ }^{\mathrm{b}}$, Walter T. DixON ${ }^{\mathrm{a}}$, \\ George R. FOXCROFT ${ }^{\mathrm{a}}$ \\ ${ }^{\text {a }}$ Department of Agricultural, Food and Nutritional Science, University of Alberta, \\ Edmonton, AB, T6G 2P5, Canada \\ ${ }^{\mathrm{b}}$ Department of Obstetrics and Gynecology, University of Florida, Gainesville, \\ Florida, 32610-0294, USA
}

(Received 1 February 2002; accepted 6 July 2002)

\begin{abstract}
The mechanisms regulating oviduct function were investigated. In Experiment 1, porcine oviductal secretory protein (pOSP) mRNA, and pOSP and insulin-like growth factor (IGF-I) in oviductal flushings, decreased through the peri-ovulatory period. In Experiment 2, higher plasma steroids in oviductal veins, ipsilateral (INT), rather than contralateral (OVX), to the remaining ovary in unilaterally ovariectomized gilts, were associated with higher pOSP in INT oviductal flushings. In Experiment 3, oviduct function was assessed as part of a collaborative study in cyclic gilts. Feed restriction in the late, compared to the early, luteal phase reduced estradiol concentrations in oviductal plasma, pOSP mRNA in oviductal tissue, and IGF-I concentrations and pOSP abundance in oviduct flushings. Previous insulin treatment differentially affected oviduct function. These data provide the first direct evidence for effects of previous feed restriction and insulin treatment on the oviduct environment in the peri-ovulatory period, which may contribute to nutritional effects on embryonic survival.
\end{abstract}

oviduct / steroids / porcine oviduct secretory protein (pOSP) / IGF-I / pig

\footnotetext{
* Correspondence and reprints

E-mail: snovak@afns.ualberta.ca
} 


\section{INTRODUCTION}

The oviduct secretes specific proteins and growth factors during the peri-ovulatory period that may play an active role in the maturation of gametes, fertilization and embryonic viability (reviewed in [12]). Coculture of oviduct epithelial cells and/or oviduct fluid with gametes or embryos in vitro has been shown to be beneficial to fertilization [14, 23, 28] and embryonic development $[15,30]$ in different species. In vivo, however, changes in the oviductal environment are very dynamic and the regulation of this changing environment is largely dependent on major changes in ovarian steroid secretion during the peri-ovulatory period. Furthermore, substantive evidence from studies in the pig indicates that both the absolute concentrations of ovarian steroids, and the temporal relationships between $\mathrm{E}_{2}$ and $\mathrm{P}_{4}$, are important to embryonic survival $[5,27]$. Specific patterns of feed restriction during the estrous cycle [1] and high feed intakes after ovulation [17] in gilts, reduce post-ovulatory progesterone concentrations and embryonic survival at d 28 of pregnancy. Although nutritionallymediated effects on subsequent fertility can be attributed to the effects on oocyte quality [32], endocrine consequences of the effects on folliculogenesis [3] and luteal function [21] could influence the steroid priming of the oviductal environment.

The time interval between ovulation and the onset of estrus is highly variable in gilts [2], suggesting that the time of ovulation should ideally be used as the key physiological time-point from which to characterize temporal changes in the oviduct environment during the peri-ovulatory period. Therefore, the first objective of this study was to describe temporal changes in porcine oviductal secretory proteins 1-3 (pOSP) and IGF-I in oviduct flushings, pOSP mRNA in oviduct tissue, and oviductal and peripheral plasma $\mathrm{E}_{2}$ and $\mathrm{P}_{4}$ concentration, during the peri-ovulatory period, using transcutaneous ultrasonography to determine the time of ovulation. We chose pOSPs as biologically relevant markers of the oviduct environment because they are synthesized by the oviduct in response to $\mathrm{E}_{2}$ [9], and improve blastocyst development in vitro [18]. IGF-I was chosen as another relevant marker because it is present in the highest concentrations in oviduct fluid during estrus in the pig [29], and is reported to increase the proportion of bovine embryos developing to the blastocyst stage in vitro [22].

Due to the presence of a sub-ovarian counter-current system [19], steroid concentrations are 10-fold higher in the oviductal, compared to the peripheral, vasculature [26] and may be functionally important in the local regulation of the oviductal environment [24]. Therefore, in a second experiment, we used unilaterally ovariectomized gilts to test the hypothesis that the local oviductal steroid concentrations control the local oviduct environment by monitoring pOSP, IGF-I and total protein concentrations in flushings collected after ovulation from the oviduct ipsilateral or contralateral to the remaining ovary.

Finally, we wished to determine whether changes in the oviductal environment could be a potential factor in nutritionally-induced effects on embryonic loss in the gilt. Therefore, using an established nutritional model $[1,3]$, total protein and IGF-I concentrations, and pOSP protein abundance, in the oviduct fluid, pOSP mRNA expression in the oviductal tissue, and associations with plasma $\mathrm{P}_{4}, \mathrm{E}_{2}$, and IGF-I concentrations in the oviductal circulation were studied in the post-ovulatory period in cyclic littermate gilts subjected to different patterns of restricted feeding in the previous estrous cycle. In an extension of this experimental model, a third littermate received insulin injections during feed restriction, which counteracted the negative effects of feed restriction on follicular growth and steroidogenesis [7]. 


\section{MATERIALS AND METHODS}

\subsection{Animals for Experiments 1 and 2}

Animals in all experiments were cared for in accordance with the Canadian Council on Animal Care Guidelines with the authorization from the University of Alberta Faculty Animal Policy and Welfare Committee. The cyclic Camborough $\times$ Canabrid terminal line gilts (Pig Improvement (Canada) Ltd.) used were housed at the University of Alberta Swine Research Unit, in barns with controlled temperature and lighting. They were individually fed twice daily a total of $2.0 \times$ Energy Maintenance $(\mathrm{M}$; $461 \mathrm{~kJ} \mathrm{DE} \cdot \mathrm{kg}^{-1}$ of metabolic BW) requirements of a standard barley-wheat-soybean meal grower diet containing 14.16 MJ $\mathrm{DE} \cdot \mathrm{kg}^{-1}$ and $14 \% \mathrm{CP}$. Gilts had ad libitum access to water.

\subsection{Experiment 1}

First and second cycle gilts $(\mathrm{N}=20)$ were randomly assigned to one of five slaughter times around ovulation. The slaughter times selected were 48 to $24 \mathrm{~h}$ before ovulation (Day -2$), 24$ to $0 \mathrm{~h}$ before ovulation (Day -1$), 0$ to $24 \mathrm{~h}$ after ovulation (Day 0), 24 to $48 \mathrm{~h}$ after ovulation (Day 1 ) and 48 to $72 \mathrm{~h}$ after ovulation (Day 2). For all gilts, estrus detection was carried out every $8 \mathrm{~h}$ starting at $d 18$ of the cycle using backpressure testing during fenceline contact with a vasectomized boar. Beginning at $8 \mathrm{~h}$ after the standing reflex was first observed, the right ovary in each gilt was examined by transcutaneous ultrasonography (Pie Medical Scanner 200, model 41480, Can Medical, Kingston, Ontario), using a 5.0-7.5 MHz multiple scan angle transducer for the presence of preovulatory follicles every $8 \mathrm{~h}$. The time of ovulation was defined as the first scanning when no presumptive ovulatory follicles were seen, minus $4 \mathrm{~h}$.

Between 1 and $2 \mathrm{~h}$ before slaughter, heparinized blood samples were taken from an ear vein. All blood samples were centrifuged $\left(2200 \times g, 4{ }^{\circ} \mathrm{C}\right)$ and plasma was separated and stored at $-30{ }^{\circ} \mathrm{C}$ until assayed for $\mathrm{P}_{4}$ and $\mathrm{E}_{2}$ concentrations. Immediately after slaughter, the reproductive tracts were removed from each gilt. The ovaries were examined and confirmed as pre-ovulatory or post-ovulatory. If ovulation had occurred, corpora lutea were counted on both ovaries as a measure of ovulation rate. Both oviducts were recovered from each gilt, and occluded at both ends to prevent fluid leakage. The oviducts were dissected free of connective tissue and the rest of the reproductive tract by blunt dissection. A blunted $20 \mathrm{~g}$ needle attached to a syringe was inserted into the oviduct lumen through the uterotubal junction and the oviduct was then flushed wit $5 \mathrm{~mL}$ of physiological saline. The flushings were immediately placed on ice for transportation and then stored at $-30{ }^{\circ} \mathrm{C}$ until further analysis. Midsections of ampulla and isthmus were dissected from the oviduct, snap frozen in liquid nitrogen, and subsequently stored at $-80^{\circ} \mathrm{C}$.

\subsection{Experiment 2}

At around d 7 of their first estrous cycle, 21 gilts were unilaterally ovariectomized under halothane anesthesia, taking care to remove all ovarian tissue, but leaving the oviduct and oviductal vasculature intact, with the total duration of surgery being about one hour. Gilts were then allowed to complete one full estrous cycle to allow for ovarian compensation. Estrus detection was carried out as described in Experiment 1, except the frequency was every $12 \mathrm{~h}$. Beginning at $12 \mathrm{~h}$ after the standing reflex was first observed, the remaining ovary in each gilt was examined by the same transcutaneous ultrasonography procedure described in Experiment 1, except the frequency was changed to every $6 \mathrm{~h}$. Time of ovulation was defined as the first scanning when no presumptive ovulatory follicles were seen, minus $3 \mathrm{~h}$. The experiment was run as two 
separate replicates $(n=10$ for replicate 1 ; $n=11$ for replicate 2 ).

Twelve to twenty six hours after ovulation, heparinized blood samples from the jugular vein, and the oviduct veins ipsilateral (INT) and contralateral (OVX) to the remaining ovary, were taken under halothane anesthesia. In Replicate 1 only, additional samples were taken from a uterine vein, and mixed arterio-venous blood from the ovarian pedicle. Blood samples were centrifuged $\left(2200 \times g, 4{ }^{\circ} \mathrm{C}\right)$ and plasma was separated and stored at $-30{ }^{\circ} \mathrm{C}$ until assayed for $\mathrm{P}_{4}, \mathrm{E}_{2}$ and IGF-I concentrations. Both INT and OVX oviducts were flushed with $5 \mathrm{~mL}$ of physiological saline solution. The flushing was done while the oviduct was still attached, by inserting a flared collection funnel attached to silastic tubing, approximately $0.5 \mathrm{~cm}$ into the ampulla, through the fimbria. The collection funnel was clamped by hand to prevent leaking during the flushing procedure and flushings were collected in $15-\mathrm{mL}$ sterile graduated centrifuge tubes. The fluid was immediately placed on ice and later stored at $-30{ }^{\circ} \mathrm{C}$ until further analysis. The gilts were then euthanized with pentobarbitol (Euthansol) and the oviducts were immediately dissected from the reproductive tract. Oviducts were trimmed free of connective tissue and midsections of the isthmus and ampulla were snap frozen in liquid nitrogen, and stored at $-80{ }^{\circ} \mathrm{C}$.

\subsection{Experiment 3}

The selection and management of gilts on the experiment, and treatment allocation, have been described elsewhere in detail [3]. Briefly, 19 littermate trios of Camborough $x$ Canabrid gilts (Pig Improvement (Canada) Ltd., Acme, AB, Canada) were randomly allocated to one of three treatments within the litter. RH gilts were fed $2.1 \times$ Energy Maintenance Requirements (M) from d 1 to $\mathrm{d} 7$ of the estrous cycle, then feed was increased to $2.8 \times \mathrm{M}$ from $\mathrm{d} 8$ to $\mathrm{d} 15$. The pattern of feeding in HR gilts was reversed, providing $2.8 \times \mathrm{M}$ from $\mathrm{d} 1$ to $\mathrm{d} 7$, and $2.1 \times$ $M$ from d 8 to $\mathrm{d} 15$. HR+I gilts were fed as HR but received long-acting insulin injections $\left(0.4 \mathrm{IU} \cdot \mathrm{kg}^{-1} \mathrm{BW}\right.$, Iletin Lente Insulin, Pork, Eli Lilly, Indianapolis, IN) twice-daily during the period of restriction. The gilts were monitored for blood glucose concentrations $3 \mathrm{~h}$ after the afternoon feed on $\mathrm{d} 8,12$, and 15 using a glucometer (One-Touch II, Lifescan inc., Milpitas, CA) and provided corn-oil supplementation $(30 \mathrm{~mL}$ which corresponded to an increment of $300 \mathrm{kcal}$ in daily energy intake) to avoid acute hypoglycemia during the period of insulin treatment. All results concerning insulin and blood glucose concentrations are published elsewhere [3]. All gilts were provided $2.8 \times \mathrm{M}$ from d 16 until breeding, at which point they were reduced to the recommended requirements for gestating gilts [25].

Gilts were checked for onset of estrus every $6 \mathrm{~h}$ from $\mathrm{d} 18$ of the treatment cycle, and were inseminated with pooled semen from the same three boars, 12 and $24 \mathrm{~h}$ after the onset of estrus. Transcutaneous ultrasonography was performed every $6 \mathrm{~h}$ from $24 \mathrm{~h}$ after the onset of estrus to determine the time of ovulation.

Of the 57 gilts allocated to the treatment, samples from 30 gilts ( $n=10$ per treatment) were selected for analysis in the present study. The selected gilts were the same as those selected for the study of luteal function [21], on the basis of ovulation to surgery interval, peripheral plasma progesterone concentrations, and embryo developmental stage at surgery. Detailed endocrine data during the treatment period and during estrus have also been reported for 23 of these 30 gilts [3].

Twelve to twenty hours after ovulation, the gilts underwent surgery to recover earlyfertilized oocytes and oviduct flushings. The surgical procedure included laparotomy under halothane anesthesia and exposure of the oviducts and ovaries. Embryos were removed and cultured as described 
elsewhere [3], and the first oviduct flushings were transferred into $15 \mathrm{~mL}$ sterile centrifuge tubes, immediately frozen and stored at $-30{ }^{\circ} \mathrm{C}$ until further analysis. Time from flushing of the oviduct to freezing of the oviductal flushings was approximately $30 \mathrm{~min}$. Immediately after flushing each oviduct, peripheral and oviductal blood samples, and oviductal tissue were taken using procedures described in Experiment 2. The animals were recovered and subsequently sent to slaughter for recovery of the uterine tissue as part of another experiment.

\subsection{Radioimmunoassays}

Plasma $\mathrm{P}_{4}$ concentrations were determined in duplicate using an established radioimmunoassay (Coat-a-Count Progesterone, Diagnostic Products Corporation, Los Angeles, USA), previously validated for use with porcine plasma without extraction [20]. The sensitivity of the single assay in Experiment 1, defined as $86.4 \%$ of total binding, was $0.097 \mathrm{ng} \cdot \mathrm{mL}^{-1}$ and the intraassay CV was $5.7 \%$. For Experiment 2, oviductal plasma samples were pre-diluted 10- and 50-fold with a zero calibrator provided with the kit before being taken into the assay in duplicate. The sensitivity of the assay in Experiment 2, defined as $89.9 \%$ of total binding, was $0.094 \mathrm{ng} \cdot \mathrm{mL}^{-1}$. The intraand inter-assay CVs were $10.0 \%$ and $16.9 \%$, respectively. The sensitivity of the assay for Experiment 3, defined as $91.4 \%$ of total binding, was $0.09 \mathrm{ng} \cdot \mathrm{mL}^{-1}$. The intra- and inter-assay CVs were $10.0 \%$ and $10.4 \%$, respectively.

Estradiol-17 $\beta$ was extracted from plasma and determined in duplicate in a single radioimmunoassay using a double antibody kit from Diagnostics Products Corporation (Los Angeles, USA), previously validated for use with porcine plasma [31], with the modification that the second antibody was diluted 3-fold to increase sensitivity. Recovery of the radiolabelled hormone was $83.7 \pm$ $11.7 \%$, and samples were not corrected for recovery. The assay sensitivity for the single assay run for Experiments 1 and 3 combined, defined as $84.0 \%$ of total binding, was $0.3206 \mathrm{pg} /$ tube and the intra-assay CV was $7.2 \%$. Experiment 2 treatment samples were balanced across assays, assay sensitivity defined as $85.8 \%$ of total binding, was $0.39 \mathrm{pg} \cdot \mathrm{mL}^{-1}$ and inter- and intra-assay coefficients of variance were $22.1 \%$ and $7.8 \%$, respectively. The $\mathrm{E}_{2}: \mathrm{P}_{4}(\mathrm{E}: \mathrm{P})$ ratio was calculated as the $\mathrm{E}_{2}$ concentration $/ \mathrm{P}_{4}$ concentration in a particular sample.

IGF-I concentration in peripheral and oviductal plasma was determined using the homologous double antibody radioimmunoassay described previously [13]. The anti-human IGF-I antiserum (product name AFP4892898, obtained from Dr. AF Parlow through the NIDDK's National Hormone and Pituitary Program), was used at a $1 / 654000$ final dilution, resulting in $38 \%$ specific binding. The single assay run for samples from Experiments 1, 2, and 3, had an intra-assay coefficient of variance of $6.9 \%$ and the sensitivity, defined as $93.7 \%$ of total bound, was $0.015 \mathrm{ng} /$ tube. Recovery efficiency was $86.6 \pm 2.5 \%$ and sample potencies were not corrected for recovery.

IGF-I concentration in oviduct fluid was determined using the same assay described above, with modifications to the extraction procedure. To concentrate the samples sufficiently for detection, $0.5 \mathrm{~mL}$ or $1 \mathrm{~mL}$ of oviduct flushings were lyophilized, reconstituted in $0.4 \mathrm{~mL}$ assay buffer (PBS containing $0.1 \%(\mathrm{w} / \mathrm{v})$ gelatin, $\mathrm{pH} 7.0)$, and extracted to remove bound proteins. Finally, $300 \mu \mathrm{L}$ of neutralized acid extract was taken into the assay to ensure that the binding produced by experimental samples fell on the linear portion of the standard curve. Diluted oviduct fluid samples showed parallelism to the standard curve. Recovery efficiency was $98.6 \pm 4.4 \%$, and samples were not corrected for recovery. The assay sensitivity for the single assay run for both Experiment 1 and 2, defined as $98.8 \%$ binding, was $0.00195 \mathrm{ng} /$ tube and the intra-assay CV was $11.46 \%$. For Experiment 3, recovery 
efficiency was $72.7 \pm 7.9 \%$, and the samples were corrected for recovery. The assay sensitivity for the single assay run for Experiment 3, defined as $94.5 \%$ of total binding, was $6 \mathrm{pg} \cdot \mathrm{mL}^{-1}$ and intra-assay $\mathrm{CV}$ was $10.5 \%$.

\subsection{Oviduct fluid protein determination and Western blotting}

Oviduct flushings were thawed on ice, the volume was recorded, centrifuged $(2200 \times g$, $4{ }^{\circ} \mathrm{C}$ ) for $10 \mathrm{~min}$, and then dialyzed against $10 \mathrm{mM}$ Tris buffer $\left(4 \mathrm{~L}, 4^{\circ} \mathrm{C}\right)$ for $24 \mathrm{~h}$ with one change. Samples were then assayed for total protein content using the BCA assay by Pierce according to the manufacturers instructions with BSA as a standard. Five micrograms of total protein from experimental samples, and from a positive (pooled oviduct fluid collected at estrus) and negative (pooled oviduct fluid collected at d 28 of pregnancy) control, were loaded onto $10 \%(\mathrm{w} / \mathrm{v})$ SDS-PAGE gels in duplicate. After electrophoresis, one gel was silver stained to correct for protein loading and the other was transferred onto an ECLHybond (Amersham Pharmacia Biotech, Baie d'Urfé, Canada) nitrocellulose membrane. Non-specific binding was blocked in $5 \%$ (w/v) BSA in TBS- $0.1 \%$ Tween-20 for $1 \mathrm{~h}$, and the blots were incubated with polyclonal antibody against pOSP $1-3$ at a 1:8000 dilution for $1 \mathrm{~h}$. This antibody has been reported to be specific for pOSP 1-3 in pigs [10]. Horseradish-peroxidase conjugated goat anti-rabbit $\operatorname{IgG}(1: 4000)$ as the secondary antibody was incubated for 20 min with the blots. Immunoreactive proteins were detected using the Western blotting ECL system as directed by the manufacturer (Amersham Pharmacia Biotech, Baie d'Urfé, Canada). Protein bands for pOSP 1, and 2-3 were quantified using densitometric techniques (Molecular Analyst v2.01, Bio-Rad Labs, Richmond, CA), values were grouped together, and collectively termed pOSP. pOSP abundance was expressed as a proportion of the positive control sample density and corrected for protein loading on the corresponding silverstained gel. The control sample was run with each blot to allow for standardization of the blots and comparison across the gels. The average densitometric value of duplicate samples was used for statistical analysis.

\subsection{POSP mRNA expression analysis}

For Experiment 1, a subset of 14 animals ( $n=3,3,3,2$, and 3 gilts, for Days -2 to 2 , respectively), selected on the basis of normal plasma $\mathrm{P}_{4}$ and $\mathrm{E}_{2}$ concentrations, were used for analysis of steady-state levels of pOSP mRNA. A subset of 7 animals, based on the timing of ovulation to surgery interval and oviductal $\mathrm{P}_{4}$ and $\mathrm{E}_{2}$ concentrations, were used for mRNA analysis of pOSP in Experiment 2. The analysis of oviductal pOSP mRNA was successfully completed in oviduct tissues from 22 animals ( $8 \mathrm{HR}$, $7 \mathrm{HR}+\mathrm{I}$, and $7 \mathrm{RH}$ ) from Experiment 3. Total RNA was extracted, quantified, and RNA integrity was assessed according to the protocols outlined elsewhere [21]. The RNA was prepared for Northern blotting as previously described [13]. Blots were then hybridized overnight in fresh prehybridization solution using a $0.8 \mathrm{~kb}$ cDNA for pOSP, to assess steady state mRNA levels. The message detected by the probe is for pOSP 1 , 2 , and 3 since they are products of the same gene [11]. The cDNA fragment was labeled with $\left[\mathrm{P}^{32}\right]$-dATP (Amersham Pharmacia Biotech, Baie d'Urfé, Canada) using a Random Primed DNA labeling kit according to the manufacturer's instructions (Life Technologies, Gaithersburg, MD). Unincorporated nucleotides were removed using G-50 Sephadex Nick Columns (Amersham Pharmacia Biotech, Baie d'Urfé, Canada). After hybridization, the blots were prepared as previously described, and the blots were exposed to BioMAX MS film (Eastman Kodak, Rochester, NY, USA) for $24 \mathrm{~h}$ at $-80{ }^{\circ} \mathrm{C}$ with 2 intensifying screens. All RNA data were quantified using densitometric techniques, normalized for loading using 
28S bands and are expressed as pOSP mRNA abundance/28S in arbitrary units.

\subsection{Statistical analysis}

Normal distribution of data and variance for all experiments were checked and plasma $\mathrm{E}_{2}$ and $\mathrm{P}_{4}$ concentrations and IGF-I concentrations in oviduct flushings were log transformed to achieve normality. Multiple comparisons of the means were analyzed using the method of Tukey's Honestly Significant Difference. If unequal sample sizes existed, the Least Squares Difference test was used to compare differences of means. Both tests were only performed if the statistical model and treatment was significant $(P<0.05)$. Gilt was considered the experimental unit in all statistical analyses. For all experiments, data were not corrected for ovulation rate as it did not affect any of the parameters. All correlations were carried out using linear regression analysis (SAS Inst. Inc., Cary, NC). The data are presented as LSM $( \pm$ SE of LSM).

For Experiment 1, plasma hormone concentrations were analyzed using the GLM procedure of SAS: the model used was an ANOVA, which included Day relative to ovulation as the independent variable and variance across animals as the error term. Data from oviduct flushings (2 oviducts per gilt) were analyzed by the GLM procedure of SAS, using day and gilt within Day relative to ovulation, as the independent variables and variation across animals within Day as the error term.

For experiment 2, plasma hormone concentrations at each sampling site were analyzed using the GLM procedure of SAS: the model included Site of sampling, and the replicate as the independent variables (except for uterine and mixed ovarian blood), Time after ovulation as the covariate, and variance across animals as the error term. There were no effects of the replicate on hormone data. The oviduct flushing measurements for INT and OVX oviducts, were analyzed by the GLM procedure of SAS using the Replicate (except for IGF-I concentrations), Treatment (INT and OVX) as the independent variables, time after ovulation as a covariate, and the variation across animals as the error term. There was no effect of the replicate or treatment by replicate interaction on any parameter. pOSP mRNA abundance was analyzed using Treatment, Section (ampulla or isthmus) and Treatment by Section as independent variables, with Time after ovulation as a covariate, and variation across animals as the error term.

For Experiment 3, plasma data were analyzed as a complete randomized block design using the general linear model of SAS and the complete model included littermate and treatment as the main effects, using ovulation to surgery time (time) as a covariate. Oviductal flushing data were analyzed using the same model, and variation across animals was the error term. In both cases, if time was significant $(P<0.05)$ as a covariate, then the time $\times$ treatment interaction was tested for significance $(P<0.05)$, using time $\times$ treatment as a covariate. Lastly, with respect to oviductal tissue pOSP mRNA, treatment, littermate, and section (ampulla and isthmus) were tested as sources of variation, with time as a covariate, and variation across animals as the error term. To test time-dependent relationships for mRNA expression, treatment and time were tested as effects, and if time was significant in the model, then time $\times$ treatment interactions were tested to determine if slopes were heterogeneous between the treatments.

\section{RESULTS}

\subsection{Experiment 1}

\subsubsection{Plasma $P_{4}, E_{2}$ and IGF-I concentrations, and E:P Ratio}

$\mathrm{P}_{4}$ concentrations $(P=0.0001)$ and E:P Ratio $(P=0.0001)$, but not $\mathrm{E}_{2}$ concentrations, varied during the peri-ovulatory period (Day -2 to 2 ) (Tab. I). IGF-I 
concentrations in plasma did not change between Day $-2\left(164.3 \pm 15.0 \mathrm{ng} \cdot \mathrm{mL}^{-1}\right)$, Day $0\left(143.51 \pm 11.6 \mathrm{ng} \cdot \mathrm{mL}^{-1}\right)$, Day 1 $\left(124.2 \pm 26.0 \mathrm{ng} \cdot \mathrm{mL}^{-1}\right)$, and Day $2(132.0 \pm$ $\left.13.0 \mathrm{ng} \cdot \mathrm{mL}^{-1}\right)$.

\subsubsection{Oviduct flushings}

Total volume recovered did not change with time; however total protein concentration $(P=0.012)$ in oviduct flushings was different across days (Tab. I). Total protein concentrations were correlated with the E:P ratio $(r=0.48, P=0.05)$ and negatively correlated to $\mathrm{P}_{4}$ concentrations $(r=-0.44$, $P=0.05)$ in peripheral plasma, within the sample, irrespective of time.

IGF-I concentrations in oviduct flushings were higher $(P=0.0001)$ at Day -2 , while Day -1 was intermediate, compared to Day 0, Day 1 and Day 2 (Tab. I), and were correlated to total protein concentrations in oviduct flushings within gilt $(r=0.46$, $P=0.004)$. IGF-I concentrations were also strongly correlated to the E:P ratio in peripheral plasma ( $r=0.70, P=0.002)$, within gilt, irrespective of time.

The Western blotting technique for the pOSP protein resulted in immunoreactive protein bands migrating at $88 \mathrm{kDa}$ and $115 \mathrm{kDa}$ (Fig. 1A). These bands correspond to the $85 \mathrm{kDA}$ pOSP 1 , and the $100 \mathrm{kDA}$ pOSP 2-3 that migrate as one $115 \mathrm{kDa}$ band on a 1 D SDS-PAGE gel [1], and are collectively referred to as pOSP. Specific binding of the primary and secondary antibody was confirmed by the lack of immunoreactive staining in the negative control pool of oviduct flushings obtained from d 28 pregnant gilts. pOSP protein abundance was lower in Day 2 oviductal flushings as compared to other days (Tab. I). However, when pOSP was expressed as a concentration in oviduct flushings (pOSP abundance $\times$ total protein concentration), there was an intermediate effect of Day 0 and Day 1 on pOSP concentration, compared to Days 2, and Days -2 and -1 (Tab. I). Plasma $\mathrm{P}_{4}$ con- centrations were negatively correlated with pOSP abundance $(r=-0.48, P=0.04)$ and pOSP concentration $(r=-0.67, P=0.002)$ in oviduct flushings within gilt.

\subsubsection{Oviduct tissue analysis}

Northern blot analysis of pOSP mRNA revealed hybridization bands at approximately $2.25 \mathrm{~Kb}$ (Fig. 1B). There was a significant effect $(P=0.01)$ of Day on pOSP mRNA abundance, since mRNA expression had almost completely disappeared by Day 1 and was gone by Day 2 (Fig. 1B). pOSP mRNA abundance was highly correlated with the E:P ratio $(r=0.75, P=0.005)$ and inversely related to plasma $\mathrm{P}_{4}$ concentrations within gilt $(r=-0.73, P=0.004)$.

\subsection{Experiment 2}

\subsubsection{Reproductive characteristics}

The average cycle length prior to sample collection was $20.4 \pm 0.4 \mathrm{~d}$, and was not different between replicates. The ovulation to surgery interval $(20.7 \pm 1.0 \mathrm{~h})$, or onset of estrus to ovulation $(34.1 \pm 1.9 \mathrm{~h})$, was not different $(P>0.05)$ between replicates. The average number of corpora lutea in Replicate 1 gilts was $13.3 \pm 1.3$. Due to the misappropriation of records, ovulation rate data for Replicate 2 are not available.

\subsubsection{Plasma $P_{4}, E_{2}$ and IGF-I concentrations and $E: P$ ratio}

Steroid concentrations differed $(P=0.0001)$ across the site of sampling, with concentrations of ovarian plasma $40-\left(\mathrm{E}_{2}\right)$ to $400-\left(\mathrm{P}_{4}\right)$ times higher, and INT oviduct 7- $\left(\mathrm{E}_{2}\right)$ to 40- $\left(\mathrm{P}_{4}\right)$ times higher than peripheral plasma, confirming the existence of the counter-current multiplier. $\mathrm{E}_{2}$ and $\mathrm{P}_{4}$ concentrations in OVX oviduct and uterine plasma were similar to peripheral $\mathrm{E}_{2}$ and $\mathrm{P}_{4}$ concentrations (Fig. 2). As a consequence of the differences in $\mathrm{E}_{2}$ and $\mathrm{P}_{4}$ concentrations in plasma, 


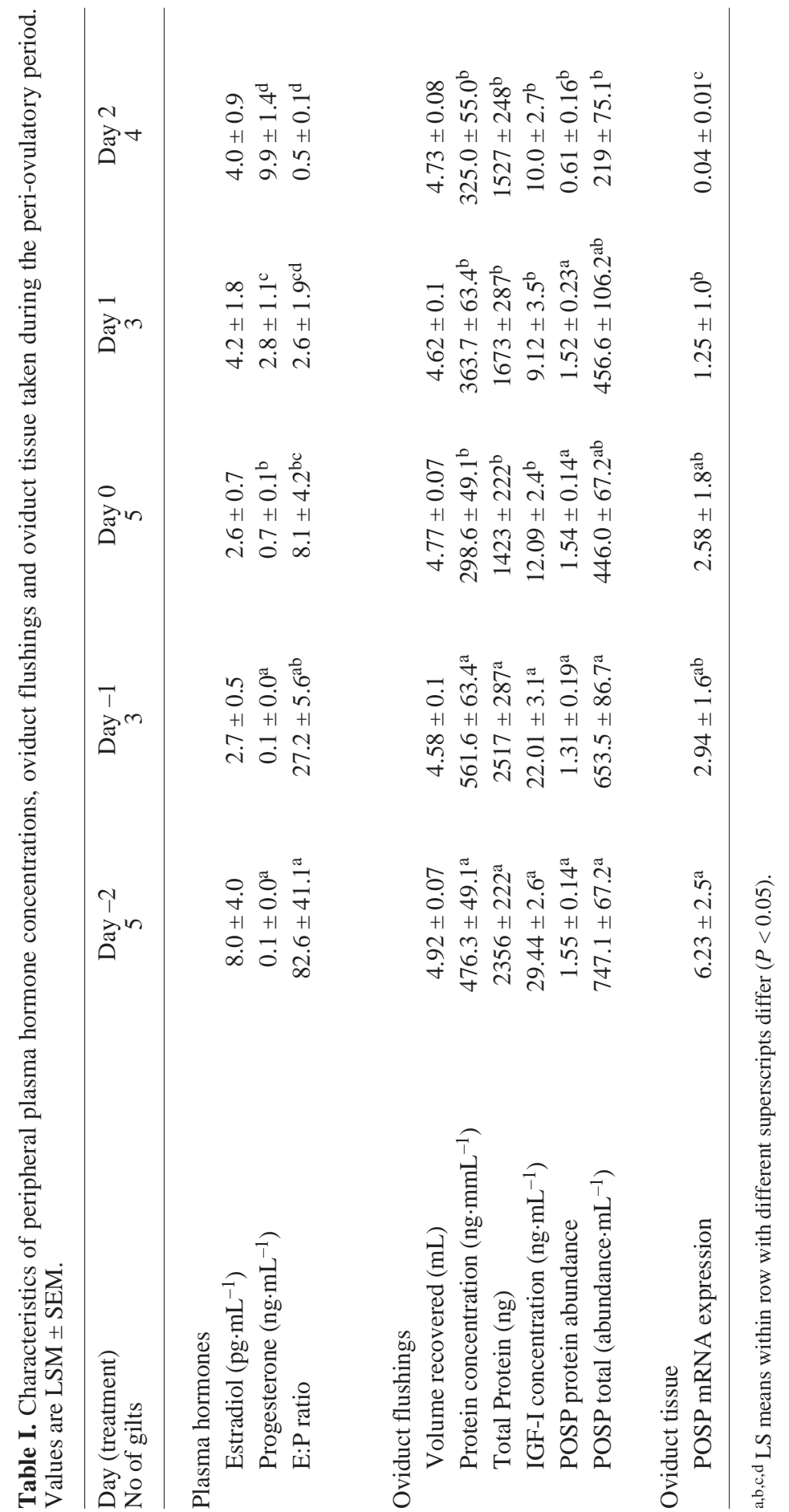


A)
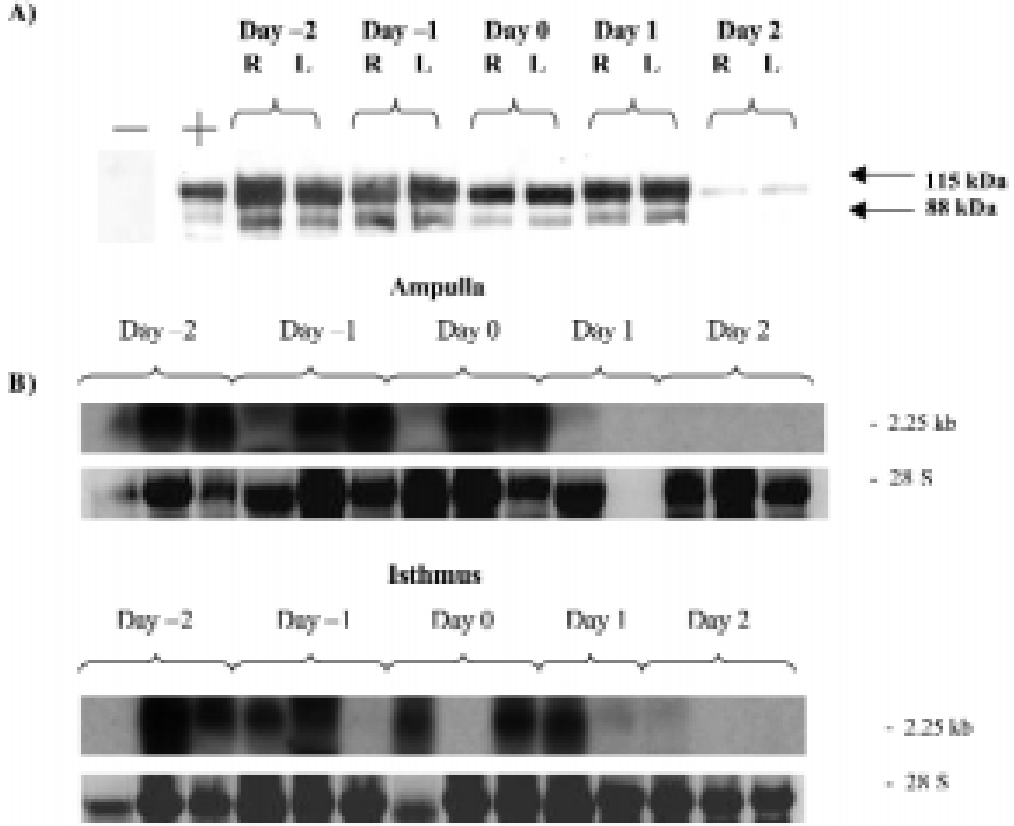

Figure 1. (A) Representative Western blot of pOSP 1-3 (pOSP) in oviduct flushings of five gilts slaughtered between Day -2 to Day 2 with respect to day of ovulation. Immunoreactive bands were detected migrating at approximately $88 \mathrm{kDa}$ and $115 \mathrm{kDa}$. The $88 \mathrm{kDa}$ band corresponds to pOSP 1 , and pOSP $2-3$ are the $115 \mathrm{kDa}$ band as they migrate together on 1-D SDS-PAGE gels. Positive control (+) and Negative Controls (-) are indicated. The negative Control Pool is pooled oviduct flushings collected from Day 28 pregnant gilts. (B) Northern blot of pOSP mRNA from 14 gilts across days ( $n=3$ gilts for Days $-2,-1,0$, and 2 , and $n=2$ gilts for Day 1 ) relative to ovulation. Ampulla and isthmus samples are shown separately. 28s mRNA bands on the corresponding gel are shown below each panel.

the E:P ratio was different $(P=0.0001)$ across the site of sampling. The E:P ratios in plasma from jugular $(1.04 \pm 0.16)$, uterine $(0.71 \pm 0.23)$, and OVX oviductal $(0.94 \pm$ $0.16)$ veins were not different from each other; however, the E:P ratio at these three sites was different from the INT oviductal vein and mixed ovarian blood $(0.17 \pm 0.15$ and $0.13 \pm 0.23$, respectively).

Due to sample availability, data on IGF-I concentrations in plasma and oviduct flushings were only available for jugular, and INT and OVX oviductal vein samples ( $n=8$ gilts) from Replicate 2. There were no differences in plasma IGF-I concentrations across jugular, INT oviduct and OVX oviduct veins (Fig. 2).

\subsubsection{Oviduct flushings}

Total volume of flushings recovered was not different between the site and replicate. However, total protein concentration was lower $(P=0.026)$ in INT oviduct compared to the OVX oviduct (Tab. II). IGF-I concentrations in oviduct flushings did not differ between INT and OVX oviducts (Tab. II). However, IGF-I concentrations in oviduct flushings were positively correlated with total protein concentration in oviduct flushings $(r=0.509, P=0.05)$.

pOSP abundance was lower $(P=0.0001)$ in OVX oviductal flushings as compared to INT oviductal flushings (Tab. II), when 
expressed as per $\mu \mathrm{g}$ total protein. However, when converted to pOSP protein concentrations (pOSP abundance $\times$ total protein concentration), there was no difference between INT and OVX oviducts (Tab. II). pOSP protein abundance in oviductal flushings was positively correlated with $\mathrm{P}_{4}$ and $\mathrm{E}_{2}$ concentrations within the oviduct.

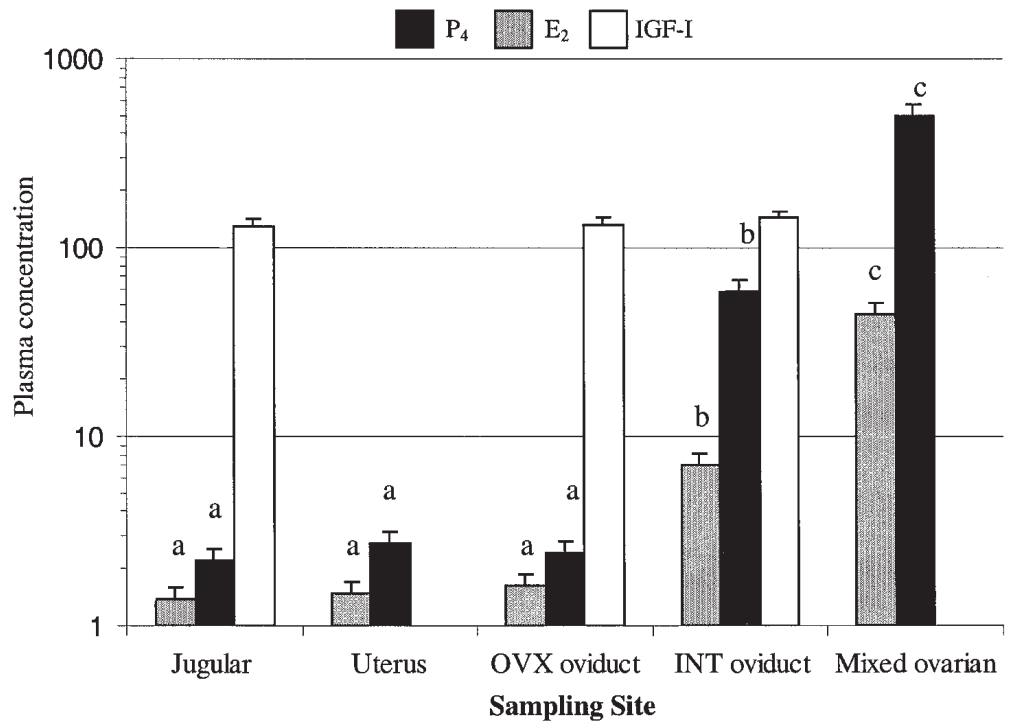

Figure 2. Least squares means $\left( \pm \mathrm{SE}\right.$ of LSM) for plasma progesterone $\left(\mathrm{P}_{4} ; \mathrm{ng} \cdot \mathrm{mL}^{-1}\right)$ estradiol $\left(\mathrm{E}_{2}\right.$; $\left.\mathrm{pg} \cdot \mathrm{mL}^{-1}\right)$, and IGF-I (ng. $\left.\mathrm{mL}^{-1}\right)$ concentrations in different sampling sites; Jugular ( $n=15$ gilts, Replicate 1 and 2), Uterine ( $n=7$ gilts, Replicate 1), oviductal veins contralateral (OVX oviduct) ( $n=15$ gilts, Replicate 1 and 2 ) and ipsilateral (INT oviduct, Replicate 1 and 2$)$ ( $n=15$ gilts) to the remaining ovary, and Mixed ovarian blood ( $n=7$ gilts, Replicate 1$)$. IGF-I was only measured in Jugular, OVX and INT oviduct vein samples $(n=8$ gilts for each site, Replicate 2$)$. Note the log scale. ${ }^{a, b, c}$ LS means within hormone with different superscripts differ by site of sampling $(P<0.05)$.

Table II. Characteristics of oviduct flushings and oviduct tissue taken at surgery in unilaterally ovariectomized gilts 12 to $26 \mathrm{~h}$ after ovulation. Values are LSM \pm SEM. For all parameters, data from the 15 gilts are represented, except for IGF-I concentration, where only values from 8 gilts are represented.

\begin{tabular}{lcc}
\hline Treatment & INT & OVX \\
\hline Oviduct flushings & & \\
$\quad$ Volume recovered $(\mathrm{mL})$ & $3.33 \pm 0.18$ & $3.53 \pm 0.24$ \\
$\quad$ Protein concentration $\left(\mathrm{ng} \cdot \mathrm{mL}^{-1}\right)$ & $503.2 \pm 135^{\mathrm{a}}$ & $868.7 \pm 135^{\mathrm{b}}$ \\
$\quad$ Total Protein $(\mathrm{ng})$ & $1532 \pm 397^{\mathrm{a}}$ & $2479 \pm 484^{\mathrm{b}}$ \\
$\quad$ IGF-I concentration $\left(\mathrm{ng} \cdot \mathrm{mL}^{-1}\right)$ & $2.49 \pm 0.14^{\mathrm{a}}$ & $9.53 \pm 0$ \\
$\quad$ POSP protein abundance & $1116 \pm 204$ & $1251 \pm 0.14^{\mathrm{b}}$ \\
$\quad$ POSP total (abundance $\left.\cdot \mathrm{mL}^{-1}\right)$ & & \\
Oviduct tissue & $0.56 \pm 0.15$ & $0.62 \pm 0.18$ \\
$\quad$ POSP mRNA expression & \\
\hline
\end{tabular}

a,b LS means within row with different superscripts differ $(P<0.05)$. 


\subsubsection{Oviduct tissue analysis}

There were no differences in pOSP mRNA expression over time, between the ampulla and isthmus or due to a unilateral ovariectomy as determined on Northern blots (data not shown).

\subsection{Experiment 3}

\subsubsection{General}

There were no treatment differences for the time interval between ovulation and surgery $(15.4 \pm 0.7,14.4 \pm 0.7$, and $14.9 \pm$ $0.7 \mathrm{~h}$ for RH, HR and HR+I groups, respec- tively), ovulation rate $(17.2 \pm 0.8,16.7 \pm$ 0.8 and $18.2 \pm 0.8$ for RH, HR, and HR+I groups, respectively), or the time interval between the onset of estrus and ovulation $(41.2 \pm 1.6,38.2 \pm 1.5$, and $41.4 \pm 1.5 \mathrm{~h}$ for RH, HR, and HR+I groups, respectively). There were no effects of ovulation rate on any of the parameters measured.

\subsubsection{Plasma $P_{4}, E_{2}$ and IGF-I concentrations and $E: P$ ratio}

Peripheral and oviductal plasma $\mathrm{P}_{4}, \mathrm{E}_{2}$ and IGF-I concentrations and the E:P ratio are summarized in Table III. Treatment effects on plasma hormones in Table III

Table III. Peripheral and oviductal steroid and IGF-I concentrations and characteristics of oviduct flushings and oviduct tissue, at surgery 12 to $20 \mathrm{~h}$ after ovulation in Experiment 3.

\begin{tabular}{|c|c|c|c|}
\hline Treatment $^{*}$ & RH & HR & $\mathrm{HR}+\mathrm{I}$ \\
\hline \multicolumn{4}{|l|}{ Peripheral plasma } \\
\hline Progesterone $\left(\mathrm{ng} \cdot \mathrm{mL}^{-1}\right)$ & $1.89 \pm 0.25$ & $1.80 \pm 0.27$ & $1.64 \pm 0.25$ \\
\hline Estradiol $\left(\mathrm{pg} \cdot \mathrm{mL}^{-1}\right)$ & $1.16 \pm 0.11$ & $0.86 \pm 0.12$ & $1.15 \pm 0.11$ \\
\hline E:P Ratio & $0.87 \pm 0.08$ & $0.87 \pm 0.08$ & $0.84 \pm 0.08$ \\
\hline IGF-I $\left(\mathrm{ng} \cdot \mathrm{mL}^{-1}\right)$ & $172.9 \pm 7.6^{\mathrm{a}}$ & $127.9 \pm 7.1^{\mathrm{b}}$ & $134.4 \pm 5.9^{b}$ \\
\hline \multicolumn{4}{|l|}{ Oviductal plasma } \\
\hline Progesterone $\left(\mathrm{ng} \cdot \mathrm{mL}^{-1}\right)$ & $52.5 \pm 17.0$ & $39.3 \pm 18.7$ & $56.1 \pm 17.2$ \\
\hline Estradiol $\left(\mathrm{pg} \cdot \mathrm{mL}^{-1}\right)$ & $11.1 \pm 2.3^{\mathrm{a}}$ & $1.51 \pm 2.3^{b}$ & $4.8 \pm 2.1^{\mathrm{ab}}$ \\
\hline E:P Ratio & $0.34 \pm 0.06^{\mathrm{a}}$ & $0.19 \pm 0.06^{\mathrm{b}}$ & $0.14 \pm 0.06^{\mathrm{b}}$ \\
\hline IGF-I $\left(\mathrm{ng} \cdot \mathrm{mL}^{-1}\right)$ & $147.2 \pm 6.5^{\mathrm{a}}$ & $121.4 \pm 7.0^{\mathrm{b}}$ & $127.4 \pm 6.5^{b}$ \\
\hline \multicolumn{4}{|l|}{ Oviduct flushings } \\
\hline Volume recovered $(\mathrm{mL})$ & $3.60 \pm 0.11$ & $3.49 \pm 0.10$ & $3.72 \pm 0.10$ \\
\hline Protein concentration $\left(\mathrm{ng} \cdot \mathrm{mL}^{-1}\right)$ & $240.89 \pm 16.9^{\mathrm{a}}$ & $167.1 \pm 18.5^{\mathrm{b}}$ & $162.0 \pm 17.0^{\mathrm{b}}$ \\
\hline Total Protein (ng) & $899 \pm 74.5^{\mathrm{a}}$ & $569.5 \pm 69.0^{\mathrm{b}}$ & $590.5 \pm 64.3^{\mathrm{b}}$ \\
\hline IGF-I concentration $\left(\mathrm{ng} \cdot \mathrm{mL}^{-1}\right)$ & $11.17 \pm 0.56^{\mathrm{a}}$ & $9.53 \pm 0.64^{\mathrm{ab}}$ & $8.39 \pm 0.55^{\mathrm{b}}$ \\
\hline POSP protein abundance & $2.69 \pm 0.20^{\mathrm{a}}$ & $2.41 \pm 0.23^{\mathrm{b}}$ & $1.59 \pm 0.2^{\mathrm{c}}$ \\
\hline POSP concentration (abundance $\cdot \mathrm{mL}^{-1}$ ) & $604.5 \pm 53.5^{\mathrm{a}}$ & $332.3 \pm 58.8^{\mathrm{b}}$ & $202.6 \pm 54.0^{\mathrm{b}}$ \\
\hline \multicolumn{4}{|l|}{ Oviduct tissue } \\
\hline POSP mRNA expression & $10.58 \pm 0.88^{\mathrm{a}}$ & $5.55 \pm 0.90^{\mathrm{b}}$ & $6.39 \pm 0.82^{b}$ \\
\hline
\end{tabular}

* RH: gilts on feed restriction from $\mathrm{d} 1$ to $\mathrm{d} 7$ of the estrous cycle, then on a high plane of feeding from $\mathrm{d} 8$ to the onset of estrus; HR: fed a high plane of feeding from $\mathrm{d} 1$ to $\mathrm{d} 7$ of the estrous cycle, feed restricted from $\mathrm{d} 8$ to $\mathrm{d} 15$, and then returned to high plane of feeding until the onset of estrus; and HR+I: gilts fed as HR gilts but treated with insulin from d 8 to $\mathrm{d} 15$. Data from 10 gilts per treatment are represented in this table.

${ }^{\mathrm{a}, \mathrm{b}, \mathrm{c}}$ LS means within row with different superscripts differ $(P<0.05)$. 
were limited to differences due to the pattern of feeding (RH vs. HR), except that $\mathrm{HR}+\mathrm{I}$ gilts had intermediate estradiol concentrations in oviductal plasma. IGF-I concentrations in both peripheral $(P=0.01)$ and oviductal $(P=0.03)$ plasma, and the E:P ratio in oviductal veins $(P=0.05)$ were greater in $\mathrm{RH}$ gilts than $\mathrm{HR}$ and $\mathrm{HR}+\mathrm{I}$ gilts.

There were no time by treatment interactions for any plasma components measured, but peripheral progesterone concentrations were related to time after ovulation ( $r=0.34, P=0.07)$. Littermate was significant for peripheral estradiol $(P=0.0001)$, and IGF-I $(P=0.017)$ concentrations, and the $\mathrm{E}: \mathrm{P}$ ratio $(P=0.0001)$, but not for peripheral progesterone concentrations. In oviduct plasma, the effect of littermate was evident for IGF-I concentrations $(P=0.0005)$ and the E:P ratio $(P=0.008)$, but not for estradiol or progesterone concentrations.

\subsubsection{Oviduct flushings}

Least squares means for each treatment group for the volume recovered, and total protein concentration, and IGF-I concentration are presented in Table III. There were no differences in volume recovered, but $\mathrm{RH}$ gilts had higher total protein $(P=0.01)$ and protein concentration $(P=0.0001)$ than $\mathrm{HR}$ and $\mathrm{HR}+\mathrm{I}$ gilts. Both total protein $(P=0.0001)$ and protein concentration $(P=0.0001)$ were affected by littermate.

IGF-I concentrations in oviduct flushings were affected by littermate $(P=0.0007)$ and treatment $(P=0.007)$; flushings from RH gilts had the highest concentrations, concentrations in HR gilts were intermediate, and flushings from $\mathrm{HR}+\mathrm{I}$ gilts had the lowest concentrations of IGF-I. Also, IGF-I concentrations in oviduct plasma and oviduct flushings were related across all animals $(r=0.336, P=0.032)$.

pOSP protein abundance was affected by littermate $(P=0.0003)$ and by treatment $(P=0.0009)$; the insulin treated group had lower pOSP abundance than the HR and
$\mathrm{RH}$ groups, and HR was lower than $\mathrm{RH}$ (Tab. III). Because of the effect of treatment on total protein concentration, with the $\mathrm{RH}$ group being higher than the HR and $\mathrm{HR}+\mathrm{I}$ groups, pOSP protein concentration was the highest $(P=0.0001)$ in the RH group, the lowest in the HR+I group and was intermediate in the HR group (Tab. III). pOSP protein abundance was also positively related $(r=0.53, P=0.0001)$ to IGF-I concentrations in oviduct flushings within animal. The correlation existed within group for the $\mathrm{RH}(r=0.49, P=0.04)$ and $\mathrm{HR}+\mathrm{I}(r=0.72$, $P=0.0008)$ treatment groups, but not for the HR treatment group.

\subsubsection{Oviduct tissue analysis}

pOSP mRNA expression was confirmed by the presence of a signal at approximately $2.25 \mathrm{~kb}$, which corresponds to hybridization with the pOSP cDNA probe (data not shown). A littermate effect was present for pOSP mRNA expression $(P=0.01)$. RH tissue had increased $(P=0.006)$ pOSP mRNA expression than $\mathrm{HR}$ and $\mathrm{HR}+\mathrm{I}$ tissue (Tab. III) and there was also a time $\times$ treatment effect on pOSP mRNA levels. The decline in pOSP mRNA expression over time was faster in the $\mathrm{RH}$ group $(P=0.006)$ than in the HR and HR+I groups (Fig. 3).

\section{DISCUSSION}

The ultimate objective of this study was to determine whether changes in the oviductal environment might be one mechanism mediating nutritional effects on embryonic loss in the pig. Initially, however, we wished to provide a more detailed characterization changes in oviduct function during the critical peri-estrous period during which steroid concentrations in the oviductal vasculature are subject to dramatic changes as a consequence of the sub-ovarian counter-current transfer system $[19,26]$. This is also the period in which the oviduct environment can directly influence early embryonic 


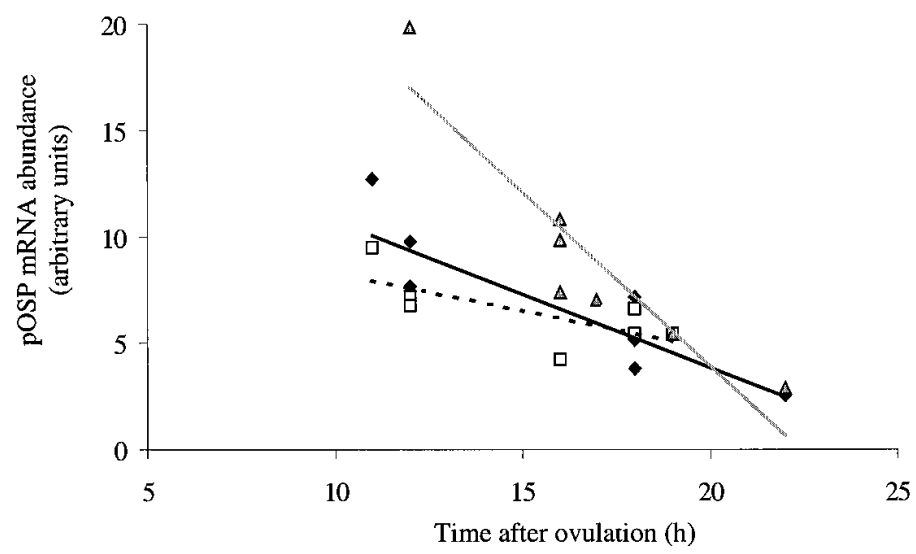

Figure 3. The relationship of pOSP mRNA abundance to time after ovulation within the treatments; $\Delta \mathrm{RH}\left(n=7\right.$ gilts, $\left.r^{2}=-0.85, P=0.0001\right), \diamond \mathrm{HR}\left(n=8\right.$ gilts, $\left.r^{2}=-0.74, P=0.03\right), \square \mathrm{HR}+\mathrm{I}$ $\left(n=7\right.$ gilts, $\left.r^{2}=-0.51, P=0.09\right)$.

development. Although previous studies have characterized IGF-I concentrations [29] and pOSP protein and mRNA abundance [11] during the estrous cycle, neither reported changes during the critical periovulatory period. Furthermore, because we have shown that the interval between the onset of estrus and the time of ovulation is highly variable in gilts, we believed it was critical to use the moment of ovulation as a critical reference point in these studies. This ensures that the data obtained reflect the physiologically important events that are triggered during the peri-ovulatory period, and particularly the rapid switch from $E_{2}$ to $\mathrm{P}_{4}$ dominance.

The observed changes in progesterone concentrations in the oviductal circulation and the consequent shift in the $\mathrm{E}: \mathrm{P}$ ratio in the peri-ovulatory period, confirmed the dynamic hormonal milieu to which the oviduct is exposed. Associated changes in the oviduct environment between the preovulatory and post-ovulatory period, with respect to total protein, IGF-I and pOSP concentration, were also established. The strong correlations between these different characteristics support the concept that the oviduct environment is indeed associated with changes in steroids in the peri-ovulatory period. In particular, the inverse relationship between protein concentrations and the concentrations of $\mathrm{P}_{4}$ is consistent with the findings of Buhi et al. [8] who showed that porcine oviductal tissue during estrus has the highest levels of de novo protein synthesis and secretion. The temporal changes in pOSP mRNA expression and the secreted pOSP proteins in relation to the time of ovulation are consistent with evidence that pOSP expression is $\mathrm{E}_{2}$-dependent [11]. Thus, as the steroid milieu of the oviduct became progesterone dominated by day 2 after ovulation, a major decline in both pOSP mRNA expression and pOSPs in oviduct fluid was observed.

Given the apparent responsiveness of the oviduct to steroid hormones in the peri-ovulatory period, and the steroid amplifying effect of the counter-current multiplier system, the next logical step in this study was to determine the extent to which the high oviductal concentrations of steroids are important for the regulation of oviduct function in vivo. The results of Experiment 2, utilizing unilateral ovariectomy as an experimental model, provide direct evidence that the concentrations of ovarian steroids in the 
local oviduct circulation exert a measurable regulatory effect on oviduct function. Oviducts obtained from ovariectomized gilts receiving exogenous estrogen have been shown to synthesize and secrete pOSP [9], which is consistent with our OVX oviduct results. However, since pOSP protein abundance was lower in the OVX oviduct, active secretion of specific oviduct-derived proteins appears to be responsive to the higher concentrations of ovarian steroids normally present in the oviductal circulation. Therefore, our data demonstrate that the presence of high physiological concentrations of steroids, as seen in the INT oviduct in the unilaterally ovariectomized gilt, may be functionally important for providing a unique environment for gametes and the developing embryo.

In contrast to its role in creating a unique steroidal milieu in the oviduct, our data indicate that the sub-ovarian counter-current system is not a multiplier for IGF-I, since there were no differences between oviductal and peripheral plasma IGF-I concentrations. This suggests that the ovary is not a significant source of IGF-I in the plasma, or that IGF-I is not transferred through the counter-current system., Jesionowska et al. [16] reported that there were no differences between IGF-I concentrations in ovarian and peripheral venous blood, which is consistent with our results. It is likely that the steric properties of IGF-I render it less capable of transfer through the countercurrent system.

Consistent with the concept of local, steroid-mediated regulation of oviduct function in pigs [24] and cows [4], in the present study the INT oviduct had lower total protein concentration than the OVX oviduct, and this may be due to an increase in fluid synthesis because of a higher $\mathrm{E}: \mathrm{P}$ ratio in the OVX side. Because we did not determine the actual fluid volume of the oviduct, we cannot exclude the possibility that fluid volume changed throughout the periovulatory period, however, high estrogen concentrations have been associated with the largest fluid volume in the oviduct during the estrous cycle [29]. Furthermore, de novo protein synthesis and secretion by explanted porcine oviducts was the highest for tissue recovered at estrus and was associated with elevated $\mathrm{E}_{2}$ concentrations [8]. Finally, in Experiment 1, the highest total protein concentration was seen in oviduct flushings in the pre-ovulatory period and was associated with a higher E:P ratio. Taken together, these data suggest that the OVX oviduct had a higher total protein concentration than the INT oviduct, likely due to both an increased protein synthetic capability and fluid synthesis. In addition, the presence of differential total protein concentrations between INT and OVX oviducts, and a positive relationship between IGF-I concentration and total protein concentrations, provides evidence for altered oviduct fluid synthesis. This may also explain why there were no differences in IGF-I concentrations in oviduct flushings between INT and OVX oviducts.

To elucidate whether the oviduct may play a role in nutritionally-mediated embryonic loss, we used an established model in which feed restriction in the second week, but not the first week of the estrous cycle, results in lower $\mathrm{P}_{4}$ concentrations in early gestation and reduced embryonic survival [1]. Nutrition affects follicular development, particularly steroidogenesis and subsequent luteal function, through metabolic hormones and metabolites acting centrally on hypothalamic regulation of LH [6], and through direct local effects on the ovary [13]. As part of the collaborative study which provided the tissues analyzed in Experiment 3, we have already established that the $\mathrm{RH}$ and $\mathrm{HR}+\mathrm{I}$ gilts had higher follicular phase $\mathrm{E}_{2}$ concentrations, a greater preovulatory $\mathrm{LH}$ surge, and a faster rise in $\mathrm{P}_{4}$ after ovulation than the HR gilts, which were considered to be indicative of greater follicular maturity and an accelerated process of luteinization $[3,21]$. Such changes in the endocrine status of gilts in the peri-ovulatory period 
clearly allow the possibility that steroiddependent effects on oviductal and uterine function will be apparent.

The higher oviductal E:P ratios in the $\mathrm{RH}$ group compared to the HR group in the present study, with intermediate levels in the $\mathrm{HR}+\mathrm{I}$ group, are generally consistent with the differences in peripheral steroid concentrations reported earlier [3]. Higher $\mathrm{E}_{2}$ concentrations, as opposed to lower $\mathrm{P}_{4}$ concentrations, also contributed to the higher $\mathrm{E}: \mathrm{P}$ ratio in $\mathrm{RH}$ gilts, and likely determined alterations in oviduct function, since the $\mathrm{RH}$ group showed higher total protein and protein concentration in the oviductal flushings. Taken together with the positive association of $\mathrm{E}: \mathrm{P}$ ratio and protein concentrations (Experiment 1), we suggest that the higher protein concentrations seen in the RH group were due to the greater $E_{2}$ peak concentrations and E:P ratios. Furthermore, POSP protein abundance and mRNA expression was also the highest in the $\mathrm{RH}$ group, and both are estrogen dependent [11]. Taken together with our previous endocrine data [3] and reported effects on luteal function [21], the results of Experiment 3 in the present study suggest a functional cascade of events in which the critical period of feed restriction during the late luteal phase in HR gilts, adversely affects folliculogenesis and subsequent luteal function, which in turn has consequences for the oviductal environment. Since the HR treatment also results in a significant reduction in embryonic survival to day 28 of gestation [1], it is possible to speculate that a less optimal oviductal environment in HR gilts during fertilization and early embryonic development contributes to reduced fertility.

Although the insulin treatment in $\mathrm{HR}+\mathrm{I}$ gilts had restored normal pre-ovulatory peak estradiol concentrations [3], insulin treatment was not associated with higher pOSP mRNA expression and $\mathrm{HR}+\mathrm{I}$ gilts had the lowest pOSP protein abundance. Although this could suggest that insulin treatment either did not counteract the effects of feed restriction on pOSP or was detrimental to the oviduct function, insulin may be differentially affecting the oviduct environment compared to feed restriction. Evidence from a separate part of this collaborative study shows that insulin treatment increased mRNA expression of key steroidogenic enzymes in luteal tissue recovered from the same gilts, and increased the sensitivity of luteal tissue in vitro to LH [21]. As shown in Figure 3, in the present study oviductal pOSP mRNA expression was low and gradually decreasing in the post-ovulatory period in the HR+I gilts. So, although oviduct fluid properties in the HR group are similar to the HR+I group, major differences in pOSP protein abundance and pOSP mRNA expression may indicate that insulin treatment advanced the oviductal environment with respect to time after ovulation, compared to the feed restricted groups.

Surprisingly, insulin treatment did not influence IGF-I concentrations in peripheral plasma, oviductal plasma or oviduct flushings. An explanation for the differences in plasma IGF-I concentration observed 12 to $24 \mathrm{~h}$ after ovulation could be that nutritionally-induced changes in folliculogenesis, although not evident in the period of follicular recruitment [3], could be further augmented during the later stages of preovulatory follicular growth. However, it is unlikely that differences in ovarian IGF-I could contribute to the differences found in this study, since previous studies have been unable to link serum IGF-I concentrations to the estrous cycle [29]. Irrespective of gilt or treatment in Experiment 3, IGF-I concentrations in oviduct plasma and oviduct flushings were related. This indicates that some of the IGF-I present in oviduct flushings may be serum derived, although as oviduct cells in vitro produce IGF-I in the pig [29], it is unclear how much the oviductal synthesis of IGF-I contributes to the IGF-I concentrations in the oviduct fluid. Interestingly, we did not find the same relationship between IGF-1 in the oviduct plasma and oviduct flushings in Experiments 1 and 2. 
However, the oviduct fluid dynamics during the peri-ovulatory period were also changing in these two experiments and IGF-I concentrations in oviduct flushings were strongly correlated with total protein concentration in oviduct flushings and the E:P ratio in plasma. This indicates that steroid driven oviduct fluid synthesis is the major determinant of IGF-I concentrations in oviduct fluid. If the majority of IGF-I present in the oviduct flushings is serum derived, it is very likely that the fluid synthesis dynamics around ovulation impact the concentration of IGF-I that is transferred into oviduct fluid. Collectively, our data suggest that either oviductal IGF-I synthesis was lower in the HR group, or that the HR treatment lowered overall IGF-I plasma concentrations and thus indirectly affected IGF-I concentrations in the oviductal flushings. Whatever mechanism regulates oviductal IGF-I concentrations, nutritional effects on IGF-I in oviductal fluid can clearly provide another mechanism for mediating effects on early embryonic development.

In conclusion, this study has provided important insights into the regulation of components of the oviductal fluid in vivo that have been implicated in embryonic development. Our data emphasize the need to evaluate the regulation of oviduct function with respect to the time of ovulation in domestic mammals. Since high steroid concentrations created by the counter-current multiplier appear to play a physiological role in creating a unique environment in the oviduct around the time of ovulation in pigs, alterations in steroid synthesis by the ovary could affect oviductal function, and affect fertilization and early embryonic development. Finally, this study provides the first evidence that previous feed restriction can affect the oviduct environment in gilts and may contribute to established differences in subsequent fertility. Although previous insulin treatment did not appear to have counteracted the effects of feeding at the oviductal level, it may have acted through other mechanisms, such as enhanced luteal function to advance the oviductal environment with respect to time after ovulation.

\section{ACKNOWLEDGEMENTS}

The authors wish to thank the NIDDK's National Hormone and Pituitary Program and Dr. A.F. Parlow from Harbor-UCLA Medical Center for the gift of IGF-I antiserum. We also acknowledge Shirley Shostak for technical assistance with radioimmunoassays, and Renate Meuser of the Molecular Biology and Biotechnology Centre for technical assistance with protein and RNA analysis. We thank the staff of both the University of Alberta Swine and Metabolic Research Units for assistance with surgeries and care of the research animals. Finally, we acknowledge the financial support of the Natural Sciences and Engineering Research Council and the Alberta Agricultural Research Institute, and Pig Improvement (Canada) Ltd for contributions to the supply of experimental animals.

\section{REFERENCES}

[1] Almeida F.R.C.L., Kirkwood R.N., Aherne F.X. Foxcroft G.R., Consequences of different patterns of feed intake during the estrous cycle in gilts on subsequent fertility, J. Anim. Sci. 78 (2000) 1556-1563.

[2] Almeida F.R.C.L., Novak S., Foxcroft G.R., The time of ovulation in relation to estrus duration in gilts, Theriogenology 53 (2000) 1389-1396.

[3] Almeida F.R.C.L., Mao J., Novak S., Cosgrove J.R., Foxcroft G.R., Effects of different patterns of feed restriction and insulin treatment during the luteal phase on reproductive, metabolic, and endocrine parameters in cyclic gilts, J. Anim. Sci. 79 (2001) 200-212.

[4] Binelli M., Hampton J., Buhi W.C., Thatcher W.W., Persistent dominant follicle alters pattern of oviductal secretory proteins from cows at estrus, Biol. Reprod. 61 (1999) 127-134.

[5] Blair R.M., Coughlin C.M., Minton J.E., Davis D.L., Peri-oestrous hormone profiles, embryonic survival and variation in embryonic development in gilts and primiparous sows, J. Reprod Fertil. 101 (1994) 167-173.

[6] Booth P.J., Craigon J., Foxcroft G.R.. Nutritional manipulation of growth and metabolic and reproductive status in prepubertal gilts, J. Anim. Sci. 72 (1994) 2415-2424. 
[7] Britt J.H., Armstrong J.D., Cox N.M., Metabolic interfaces between nutrition and reproduction in pigs, Proc. 11th Int. Congress Anim. Prod. and AI, Dublin, 1988, pp. 117-125.

[8] Buhi W.C., Alvarez I.M., Sudipong V., Dones-Smith M.M., De novo synthesis and release of polypeptides from cyclic and early pregnant porcine oviductal tissue in explant culture, Biol. Reprod. 43 (1990) 929-938.

[9] Buhi W.C., Ashworth C.J., Bazer F.W., Alvarez I.M., In vitro synthesis of oviductal secretory proteins by estrogen-treated ovariectomized gilts, J. Exp. Zool. 262 (1992) 426-435.

[10] Buhi W.C., O’Brien B., Alvarez I.M., Erdos G., Dubios D., Immunogold localization of porcine oviductal secretory proteins within the zona pellucida, perivitelline space, and plasma membrane of oviductal and uterine oocytes and early embryos, Biol. Reprod. 48 (1993) 1273-1283.

[11] Buhi W.C., Alvarez I.M., Choi I., Cleaver B.D. Simmen F.A., Molecular cloning and characterization of an estrogen-dependent porcine oviductal secretory glycoprotein, Biol. Reprod. 55 (1996) 1305-1314.

[12] Buhi W.C., Alvarez I.M., Kouba A.J., Oviductal regulation of fertilization and early embryonic development, J. Reprod. Fertil. 52 (1997) 285-300.

[13] Cosgrove J.R., Tilton J.E., Hunter M.G., Foxcroft G.R., Gonadotrophin-independent mechanisms participate in ovarian responses to realimentation in feed-restricted prepuberta gilts, Biol. Reprod. 47 (1992) 736-745.

[14] Dubuc A., Sirard M.A., Effect of coculturing spermatozoa with oviductal cells on the incidence of polyspermy in pig in vitro fertilization, Mol. Reprod. Dev. 41 (1995) 360-367.

[15] Gandolfi F., Moor R.M., Stimulation of early embryonic development in the sheep by co-culture with oviduct epithelial cells, J. Reprod. Fertil. 81 (1987) 23-28.

[16] Jesioniwska H., Hemmings R., Guyda H.J., Posner B.I., Determination of insulin and insulinlike growth factors in the ovarian circulation Fertil. Steril. 53 (1990) 88-91.

[17] Jindal R., Cosgrove J.R., Aherne F.X., Foxcrof G.R., Effect of nutrition on embryonal mortality in gilts: Association with progesterone, J. Anim. Sci. 74 (1996) 620-624.

[18] Kouba A.J., Abeydeera L.R., Alvarez I.M., Day B.N., Buhi W.C., Effects of the porcine oviductspecific glycoprotein on fertilization, polyspermy, and embryonic development in vitro, Biol. Reprod. 63 (2000) 242-250.

[19] Krzymowski T., Kotwica J., StefanczykKrzymowska S., Uterine and ovarian countercurrent pathways in the control of ovarian function in the pig, J. Reprod. Fertil. Suppl. 40 (1990) 179-191.

[20] Mao J., Foxcroft G.R., Progesterone therapy during early pregnancy and embryonic survival in primiparous weaned sows, J. Anim. Sci. 75 (1998) 1922-1928
[21] Mao J., Treacy B.K., Almeida F.R.C.L., Novak S., Dixon W.T., Foxcroft G.R., Feed restriction and insulin treatment affect subsequent luteal function in the immediate postovulatory period in pigs: progesterone production in vitro and mRNA expression for key steroidogenic enzymes, Biol. Reprod. 64 (2001) 359-367.

[22] Matsui M., Takahashi Y., Hishinuma M. Kanagawa H., Insulin and insulin-like growth factor-1 (IGF-I) stimulate the development of bovine embryos fertilized in vitro, J. Vet. Med. Sci. 57 (1995) 1109-1111.

[23] Nagai T., Moor R.M., Effect of oviduct cells on the incidence of polyspermy in pig eggs fertilized in vitro, Mol. Reprod. Dev. 26 (1990) 377-382.

[24] Nichol R., Hunter R.H.F., Cooke G.M., Oviduct fluid $\mathrm{pH}$ in intact and unilaterally ovariectomized pigs, Can. J. Physiol. Pharmacol. 75 (1997) 1069-1074.

[25] NRC., Nutrient requirements of swine, 9th ed. Washington, DC, National Academy Press, 1988.

[26] Pharazyn A., Foxcroft G.R., Aherne F.X., Temporal relationship between plasma progesterone concentrations in the utero-ovarian and jugular veins during early pregnancy in the pig, Anim. Reprod. Sci. 26 (1991) 323-332.

[27] Soede N.M., Helmond F.A., Kemp B., Peri ovulatory profiles of oestradiol, LH and progesterone in relation to oestrus and embryo mortality in multiparous sows using transrecta ultrasonography to detect ovulation, J. Reprod. Fertil. 101 (1994) 633-641.

[28] Vatzias G., Hagen D.R., Effects of porcine follicular fluid and oviduct-conditioned media on maturation and fertilization of porcine oocytes in vitro, Biol. Reprod. 60 (1999) 42-48.

[29] Wiseman D.L., Hendricks D.M., Eberhardt D.M., Bridges W.C, Identification and content of insulin-like growth factors in porcine oviductal fluid, Biol. Reprod. 47 (1992) 126-132.

[30] Xu K.P., Yadav B.R., Rorie R.W., Plante L., Betteridge K.J., King W.A., Development and viability of bovine embryo derived from oocytes matured and fertilized in vitro and co-cultured with bovine oviductal epithelial cells, J. Reprod. Fertil. 94 (1992) 33-43.

[31] Yang H., Pettigrew J.E., Johnston G.C., Shurson J.E., Wheaton J.E., White M.E., Koketsu Y., Sower A.F., Rathmacher J.A., Effects of dietary lysine during lactation on blood metabolites, hormones, and reproductive performance in primiparous sows, J. Anim. Sci. 78 (2000) 1001-1009.

[32] Zak L.J., Xu X., Hardin R.T., Foxcroft G.R., Impact of different patterns of feed intake during lactation in the primiparous sow on follicular development and oocyte maturation, J. Reprod. Fertil. 110 (1997) 99-106. 